\title{
Delito e reparação do dano, no Anteprojeto do Código Civil Brasileiro *.
}

\author{
Manoel Pedro Pimentel \\ Catedrático de Direito Penal na Faculdade de \\ Direito da Universidade de São Paulo.
}

\begin{abstract}
SumárIo: 1 Conceito de dano. 2 A reparação do dano decorrente do delito, no direito brasileiro. 3 O sistema atual. 4 A disciplina da reparação do dano ex-delicto no Anteprojeto do Código Civil Brasileiro. 5 Formas procedimentais previstas no Projeto do Código de Processo Civil e no Anteprojeto do Código de Processo Penal. 6 os efeitos civis da sentença penal condenatória, no Anteprojeto do Código Civil Brasileiro. 7 Os efeitos civis da sentença penal absolutória, no mesmo Anteprojeto; a - quanto à inexistência material do fato; b - quanto às causas de exclusão da antijuridicidade; c - quanto às causas dirimentes; d - quanto à ausência de provas: I da existência do fato; II da existência do fato tipico; III $d a$ existência da autoria ou da co-autoria, e IV ausência de provas suficientes para a condenação. 8 Contravenções e reparação do dano. 9 Conclusāo.
\end{abstract}

\section{Conceito de dano.}

Segundo lição de José Maria Stampa Braun, o delito pode ser definido como "o comportamento humano que a norma penal proíbe ou ordena, sancionando com uma pena quem o realizar ou se abstiver de realizá-lo" 1

E, na conformidade do ensinamento de Nelson HunGRIA, "todo crime produz um dano (real, efetivo) ou um

* Conferência proferida no Curso patrocinado pela Academia Paulista de Direito sobre o Anteprojeto do Código Civil Brasileiro em 23 de outubro de 1972, na Faculdade de Direito da Universidade de São Paulo.

1. Josí Maria Stampa BraUN, Introducion a la Ciencia del Derecho Penal, Miñon, S. A., Valadolid, 1953, pág. 24. 
perigo de dano (relevante possibilidade de dano, dano potencial), isto é, cria uma alteração do mundo externo que afeta a existência ou a segurança do bem ou interesse que a protege com a última ratio da sanção penal." 2

O dano, qualificado como real, efetivo, é o efeito resultante das condutas causais, nos crimes materiais e nos crimes formais, e pode ser definido como "a perda ou a diminuição de um bem, ou o sacrifício, ou a restrição de um interesse humano", consoante o correto pronunciamento de Rocco.

CÂmara Leal o conceitua como "o efeito nocivo produzido por alguma coisa, determinando, em relação à pessoa que o sofre, alguma diminuição do seu bem-estar ou do seu patrimônio" ou, em síntese, "o prejuízo material ou moral sofrido por. alguém". ${ }^{3}$

Tão antiga quanto à noção do dano é o entendimento de que o responsável pela prática de um delito, deve repará-lo. Vem do direito romano a regra et delicta et noxa caput sequuntur. ${ }^{4}$

\section{A reparação do dano decorrente do delito, no Direito Brasileiro.}

Esta concepção é da tradição do direito brasileiro. Assim já dispunha o art. 21 do Código Criminal do Império: "O delinqüiente satisfará o dano que causar com o delito", enquanto que 0 art. 22 exigia: "a satisfação será sempre a mais completa possível"

Por isso, o Código de Processo Criminal de 1832 impunha ao juiz a formulação, ao Conselho de Sentença, da questão "se há lugar à indenização?" s

2. Nelson Hungria, Comentarios ao Código Penal, Ed. Rev. For., Rio, 1949, vol. I, págs. 190/191.

3. Antonio Luiz da Camara Leal, Dos efeitos civis do julgamento criminal, Saraiva Ed., S. Paulo, 1930, pág. 31.

4. L. 1 \& 18, depositi.

5. Art. $269, \S 5$. 
A Lei n..$^{\circ} 261$ de 3 de dezembro de 1841 revogou expressamente esses dispositivos, separando a matéria criminal da civil, e dispondo que a indenização deveria ser clemandada no juízo cível. Mas, no seu art. 68, ressalvou expressamente: "Não se poderá, porém, questionar mais sobre a existência do fato e sobre quem seja o seu autor, quando estas questões se acharem decididas no crime"

Este dispositivo foi trasladado, com pequena alteração de redação, para o Código Civil vigente, em scu art. 1.525, in verbis: "A responsabilidade civil é independente da criminal: não se poderá, porém, questionar mais sobre a existência do fato, ou quem seja o seu autor, quando estas questões se acharem decididas no crime"

O Código Penal de 1890 não alterou o sistema, uma vez que, no art. 69, letra "b", impunha a "obrigação de indenizar o dano", mantendo o entendimento do diploma anterior e que veio ratificado pelo disposto no art. 159 do Código Civil, segundo o qual todo aquele que, "por ação ou omissão voluntária, negligência ou imprudência, violar direito, ou causar prejuízo, fica obrigado a reparar o dano"

Prevaleceu, portanto, o postulado de que "a ilicitude penal pressupõe sempre uma ilicitude extrapenal", na feliz expressão de Frederico MARques. ${ }^{6}$

\section{O sistema atual.}

Vige atualmente o mesmo princípio, deduzido da conjungação das normas codificadas do Direito Civil, do Direito Processual Penal e do Direito Processual Civil. Ensina o mesmo Frederico Marques que "a condenação, ao mesmo tempo que impõe a regra sancionadora da norma penal, declara que houve a prática de um ato ilícito e, conseqüentemente, de um ato que violou direito cle outrem" 7

6. Jose Frederico Marques, Tratado de Direito Penal, Ed. Saraiva, S. Paulo, 1966, 2.a ed., vol. III, pág. 290.

7. Op. loc. cit. 
Esta projeção dos efeitos da condenação penal no âmbito do direito privado decorre dos termos expressos do art. 74, I, do Código Penal vigente: "São efeitos da condenação: I, tornar certa a obrigação de indenizar o dano resultante do crime" E, como já vimos, esta obrigação vem também definida no art. 159 do Código Civil.

Correspondente a estes dispositivos é a norma do art. 63 do Código de Processo Penal atual: "Transitada em julgado a sentença condenatória, poderão promover-lhe a execução, no juízo cível, para o efeito da reparação do dano, o ofendido, seu representante legal ou seus herdeiros"

No sistema atual, portanto, a obrigação de reparar o dano decorre, em princípio, da condenação criminal, e será demandada no juízo cível, onde não poderá ser novamente questionada a existência do fato, ou quem seja o seu autor, desde que já decididas tais questões no juízo criminal. A propósito, diz Frederico Marques que "a condenação penal é, assim, um fato jurídico que traz imanente a obrigação de indenizar" 8

\section{A disciplina da reparação do dano ex-delicto no Anteprojeto do Código Civil Brasileiro.}

Trata este Anteprojeto, nos arts. 187 a 180, dos atos ilícitos, alterando a redação do atual Código Civil, para incluir o dano causado a outrém, ainda que simplesmente moral, enquanto que a lei vigente somente se refere ao prejuízo, sem esta especificação.

Dispondo no art. 187 que "aquele que, por ação ou omissão voluntária, negligência ou imprudência, violar direito e causar dano a outrém, ainda que simplesmente moral, comete ato ilícito", o Anteprojeto se manteve fiel à teoria da culpa, também chamada teoria da responsabilidade subjetiva. Entretanto, acolheu igualmente os postulados da teoria da respon-

8. Op. cit., pág. 291. 
sabilidade objetiva que, no dizer de Washington de Barros Monteiro, "se apresenta sob duas faces no direito moderno, a teoria do risco e a teoria do dano objetivo". 9

Nó́ Azevedo, com apoio em opinião erudita de Orozimbo Nonato, sustentava que os casos tidos como de responsabilidade objetiva, no Código Civil atual, eram na verdade exemplos de culpa "in vigilando" ou "in eligendo", com exceção da hipótese prevista no art. 1519. ${ }^{10}$

A teoria do risco foi francamente acolhida, por exemplo, no art. 188 do Anteprojeto, que soa: "Também comete ato ilícito o titular de um direito que, ao exercê-lo, excede manifestamente os limites impostos pelo seu fim econômico ou social, pela boa fé ou pelo bons costumes." Ou, ainda mais claramente, no art. 986, parágrafo único: "Todavia, haverá obrigação de reparar o dano, independentemente de culpa, nos casos especificados em lei, ou quando a atividado normalmente desenvolvida pelo autor do dano implicar, por sua natureza, grande risco para os direitos de outrem, salvo se comprovado o emprego de medidas preventivas tecnicamente adequadas." (Os grifos são nossos)

Agasalhou, também, a mesma teoria nos arts. 990 e 992, estatuíndo este que "As pessoas indicadas nos ns. I e III do artigo antecedente, ainda que não haja culpa de sua parte, responderão pelos atos praticados pelos terceiros ali referidos". (Grifamos) .

A teoria do dano objetivo encontrou guarida nos arts. 995, 996 e 997, que repetiram os dispostivos dos arts. 1.527, 1.528 e 1.529, com algumas modificações de redação Mas, principalmente, tornou-se patente a opção do Anteprojeto, relativamente aos postulados desta teoria, quando estabeleceu expressamente, no art. 1.003, que "A indenização não se me-

9. Washington de Barros Monteiro, Curso de Direito Civil, Saralva Ed., 6.a ed., Sáo Paulo, 1969, 5. vol., pág. 415.

10. Not Azevedo, Decisão do Juizo Criminal como coisa julgada quanto da ação civil, Emp. Grá. "Rev. dos Tribs.", São Paulo, 1933, pág. 18. 
de pela gravidade da culpa, mas pela extensão do dano", grifo nosso - dispositivo que constitui novidade.

Relativamente aos efeitos civis da sentença penal, manteve-se o Anteprojeto na mesma linha do Código atual, inscrevendo no art. 986 a obrigação de reparação do dano causado por ato ilícito, e repetindo, no art. 994, que "a responsabilidade civil é independente da criminal; não se poderá, porém, questionar mais sobre a existência do fato, ou quem seja o seu autor, quando estas questões se acharem decididas no crime"

A matéria relativa à indenização é regulada nos arts. 1.003 e seguintes do Anteprojeto, com modificações de redação, sendo que a mais importante é a que já assinalamos acima, para acolher a teoria do dano objetivo. Claro está que o acolhimento da teoria da responsabilidade objetiva apenas pode ser entendido como válido no campo do cível, pois o Direito penal exige sempre a demonstração da responsabilidade subjetiva (culpa latu sensu)

\section{Formas procedimentais previstas no projeto do Código de Processo Civil e no Anteprojeto do Código de Processo Penal.}

Manteve o Código Penal de 1969, na sua linha mestra, a posição que afirma ser um dos efeitos da condenação "tornar certa a obrigação de reparar o dano resultante do crime" (Art. 91, n. ${ }^{\circ} \mathrm{I}$ ) Paralelamente, o Projeto do Código de Processo Civil ${ }^{11}$, inclui a sentença penal transitada em julgado entre os títulos exєcutivos judiciais, estabelecendo no art. 596: "São títulos executivos judiciais: II - a sentença penal transitada em julgado, que torna certa a obrigação de o réu indenizar o dano resultante do crime." $\mathrm{E}$, no art. 595, inscreve: "Toda execução tem por base título executivo judicial ou extrajudicial." Ficou, assim, resolvida a dúvida doutrinária: A

11. Projeto n. ${ }^{\circ} 810-A$, de 1972. 
sentença penal transitada em julgado é, em si mesma, título executório também civil, independentemente da condenação à reparação do dano.

Portanto, é a forma executiva direta eleita para a reparação do dano ex-delicto, no juízo cível.

Inovação de relevo, todavia, trouxe o Anteprojeto do Código de Processo Penal, ao estabelecer, no art. 803, $\$ 1 .^{\circ}$, que "quando o juiz criminal exercer também a jurisdição civil, a execução far-se-á nos próprios autos da ação penal" Portanto, nas comarcas onde houver jurisdição cumulativa a execução se fará nos próprios autos da ação penal.

Pensamos que o novo sistema trará vantagens, de acordo com os princípios da economia processual e da concentração, mas receiamos que, na prática, resultem alguns inconvenientes em virtude do acúmulo das execuções criminal e civil nos mesmos autos.

O parágrafo $2 .^{\circ}$ desse artigo ressalva que "quando não ocorrer a hipótese prevista no parágrafo anterior, o ofendido poderá extrair carta de sentença, para executá-la no juízo cível." A carta de sentença funcionará como título executivo judicial, segundo a referida norma do Projeto do Código de Processo Civil.

\section{Os efeitos civis da sentença penal condenatória, no anteprojeto do Código Civil Brasileiro.}

Conforme ficou dito, a obrigação de indenizar, decorrente do ato ilícito, veio afirmada no art. 986 do Anteprojeto. E ficou mantida a mesma sistemática do Código Civil atual, quanto aos efeitos civis da sentença penal, projetando-se no juízo civil a decisão que resolver a respeito da existência do fato, ou quem seja o seu autor, ressalvada a independência da responsabilidade civil da responsabilidade criminal.

Relativamente à sentença penal condenatória, não são importantes as divergências. Afirmado, pelo juiz criminal, que 
o agente praticou ato ilícito incluído entre os delitos definidos em lei, a sentença condenatória projeta seus efeitos soberanamente na jurisdição civil; não se discutirá mais se o fato é criminoso e se o agente foi o seu autor A propósito, ensina W AShington de Barros Monteiro: "Efetivamente, repugna conceber que o Estado, em sua unidade, na repressão de um fato reputado como ofensivo da ordem social, decida soberanamente, por um de seus órgãos jurisdicionais, que esse fato constitui crime, que seu autor é passível de pena e o condene a sofrer o castigo legal; e que esse mesmo Estado, prosseguindo na repressão do fato antijurídico, venha a declarar, por outro ramo do Poder Judiciário, que ele não é delituoso, que é perfeitamente lícito, que não acarreta responsabilidade alguma para o seu autor, que não está assim adstrito ao dever de compor os danos a que deu causa. Chocante, ofensiva do prestígio da justiça, seria essa contradição, pela qual o mesmo ato seria, a um tempo, justo e injusto, lícito e criminoso, irrepreensível e condenável, legítimo e punível"

$\mathrm{E}$, prossegue o eminente autor: "no tocante à sentença condenatória proferida no crime, não há possibilidade de qualquer dúvida; o juiz criminal, para que possa lavrar condenação, terá que reconhceer o fato e quem seja o seu autor; nessas condições, a decisão proferida no crime, terá irretorquivelmente decisiva influência no cível; onde houve prova de dolo ou culpa criminal, capaz de determinar condenação, transparece positivamente a responsabilidade civil de reparar o dano." 12

Estas considerações doutrinárias correspondem à melhor orientação, seguida também pelo ilustre penalista Costa E Silva: "Quando, em processo criminal, se profere uma sentença condenatória, o primeiro efeito da condenação, passada em julgado, é, segundo o artigo supra, tornar certa a obrigação de indenizar. Essa obrigação tem sua origem no fato criminoso; mas a sentença condenatória, definitiva, torna-a

12. Op., cit., págs. $424 / 425$. 
insuscetível de nova discussão e apreciação. Nisso consiste a certeza a que a lei se refere." 18

Firmou-se o Anteprojeto, portanto, nessa mesma linha que já vinha sendo seguida pelo Códico Civil, mantendo o entendimento de que a sentença penal condenatória projeta soberanamente seus efeitos no juízo cível.

\section{Os efeitos civis da sentença penal absolutória, no mesmo Anteprojeto.}

Repetiu o Anteprojeto, no art. 189, ipsis verbis, o disposto no art. 160 do Código Civil vigente. Portanto, os mesmos problemas atualmente existentes na doutrina prosseguirão sem uma solução legislativa final, quanto aos efeitos civis da sentença penal absolutória.

Esta a razão que nos levará a tecer algumas considerações preliminares a respeito do assunto e, depois, procurar as soluções adequadas a cada um dos referidos problemas.

Duas foram as maneiras de encarar os efeitos civis da sentença penal absolutória, no direito brasileiro, conforme bem observou Miguel Reale: "Apontam os tratadistas duas fases fundamentais distintas no Direito pátrio no que tange à determinação no cível da eficácia da sentença penal absolutória, por negativa do fato delituoso ou de autoria: o período que da lei n. ${ }^{\circ} 261$, de 3 de dezembro de 1841, cujo artigo se trasladou para o art. 1.525 do Código Civil, vem até a promulgação do atual Código de Processos Penal; e o período surgido com as novas normas dos artigos 65 e $67 \mathrm{da}$ Lei Processual vigente." 14

O advento da Lei n. ${ }^{0} 261$, em face da redação do seu artigo 68, permitiu o entendimento autorizado de JoÃo Monteiro e Azevedo Marques, sustentando que somente

13. A. J. DA Costa E Silva, Comentários ao Código Penal, Contasa Ed., 2. ${ }^{\text {a }}$ ed., São Paulo, 1967, vol. I, pág. 276.

14. Miguel Reale, Nos quadrantes do Direito Positivo, Ed. Michalany Ltda., São Paulo, 1960, 1. ${ }^{\mathrm{a}}$ ed., pág. 381 . 
a sentença condenatória constituiria coisa julgada oponível no cível. CẦmara Leal transcreve a lição de João Monteiro "A indenização, em todos os casos, será pedida por ação civil. Não se poderá, porém, questionar mais sobre a existência do fato, e sobre quem seja o seu autor, quando estas questões se achem decididas no crime. Isto quer dizer que, quando no juízo criminal passar em julgado a sentença que condenou Pedro como autor do crime $\mathrm{X}$, se no posterior juízo civil para satisfação do dano causado por este mesmo crime $\mathrm{X}$, Pedro vier negando ou a existência ou a autoria deste crime, o autor lhe oporá a coisa julgada para que não mais sejam aqueles pontos sujeitos à discussão. Dizemos a sentença que condenou, porque parece não mais suscetível de dúvida a opinião que não vê coisa julgada na sentença de absolvição, obtida no juízo criminal, sobre a ação civil de satisfação. Nem outra pode ser a interpretação, gramatical ou lógica do nosso art. $68 \mathrm{da}$ lei de 3 de dezembro, e consoante a doutrina dos mais abalizados especialistas da matéria. Quando as questões sobre a existência do fato e sobre quem seja o seu autor estejam decididas no crime, diz a lei, e isto só pode significar que o crime ficou provado e que é autor dele a pessoa condenada. Portanto, se o indiciado foi absolvido porque não se provou ou a existência do crime ou que fosse ele o autor, tal sentença não poderá ser oposta como coisa julgada no juízo civil para impedir a ação de satisfação. E óbvia é a razão: o fato pode ser verdadeiro e outra pessoa o seu autor, ou mesmo o acusado, mas sem o concurso das condições de imputabilidade criminal." 15

A estas judiciosas considerações opôs-se Spencer VAMPRÉ, conforme relato também transcrito por CÂMARA LEAL: "ninguém negará que quando, absolvido o réu no juízo criminal, se pretende demonstrar, no juízo civil, que ele é autor do fato, suscita-se a mesma questão que já decidida, e se questiona sobre a existência do fato ou a imputação do fato

15. Op. cit., pág. 176. 
ao absolvido, - o que a sentença criminal já definitivamente resolvera. A razão que a João Monteiro parece "óbvia", segundo a nossa opinião, prova demais. A possibilidade de ser verdadeiro o fato ou de ser outra pessoa o seu autor, ou mesmo o acusado, mas sem o concurso das condições de imputabilidade criminal' - tanto se aplica às sentenças absolutórias, como às condenatórias, e, a ser admitida, permitiria que se questionasse sempre no cível sobre o fato e o seu agente, quer este tivesse sido absolvido, ou condenado." Tanto são possíveis as absolvições, como as condenações injustas, e sempre, no juízo civil, se aprecia a responsabilidade com critério e latitude diferentes das com que se apreciam no juízo criminal. Não. Não se pode, com João Monteiro, e com os que o apoiam, afirmar que as sentenças absolutórias nenhum efeito produzem no cível." 16

Parece-nos que a lição de João Monteiro não foi bem compreendida. A leitura do texto transcrito não nos convence de que fora sua intenção negar qualquer eficácia, quanto aos efeitos projetados no juízo civil, da sentença penal absolutória. A doutrina exposta pelo renomado mestre distinguia a sentença absolutória "porque não se provou ou a existência do crime ou que fosse ele o autor" E somente esta "não poderá ser oposta como coisa julgada no juízo civil para impedir a ação de satisfação"

Interpretada, assim, restritamente, a opinião de João Monteiro pode ser conciliada com a de Clovis Bevilaqua, apontada como oposta por CÂMARA LEAL quando citou o ensinamento deste: "se a lei ordena que não se questione mais no civil sobre o fato e sobre quem seja o seu autor, quando estas questões se acharem decididas no crime, não nos é lícito distinguir entre sentença absolutória e condenatória. Se o fato é verdadeiro e outra pessoa seu autor, a sentença absolutória não cria obstáculo à ação penal, senão a respeito da pessoa inocentada. Mas, se o julgamento no crime absolveu, porque o fato não

16. Op. cit., pág. 179 . 
se tenha dado, o ingresso no juízo civil está absolutamente fechado. Se a absolvição, apenas, significa não ser o indiciado criminoso, por não se verificarem as condições de imputabilidade, afirma a existência do fato e reconhece o seu autor, e no civil não se vai contestar o que a sentença criminal declarou ser verdade. E lícito, porém, exigir a indenização, porque não são reparáveis, somente, os prejuízos determinados por atos puníveis." 17

Estas distinções aclaram o assunto. Casos há em que a sentença criminal absolutória projetará peremptoriamente seus efeitos no juízo civil. Em outros, porém, apesar de absolvido, ficará o réu sujeito à demanda para a reparação do dano.

Versando o tema, e tendo em vista estas peculiaridades, Miguel Reale opinou: "Se a sentença declara apenas provável a inexistência do fato, e por tal motivo exclui a responsabilidade criminal do réu, é justo que se torne a produzir prova sobre o fato quando da apuração das responsabilidades civis. $\mathrm{O}$ mesmo acontecerá na hipótese de serem julgadas insuficientes as provas carreadas para o processocrime: em tal caso não ocorre negativa do fato, mas suspensão do juízo sobre ele, em virtude de carência de elementos de convicção. Já se não pode chegar a idêntica conclusão quando a sentença, sopesando os elementos probatórios, e mesmo apontando possíveis dúvidas, não deixa, no entanto, de concluir enunciando a convicção da existência do fato ou da autoria, na plenitude de seu peso lógico." 18

Bastam estas observações para demonstrar a necessidade de examinar-se cada caso separadamente, a fim de verificar-se em quais deles a sentença penal absolutória se impõe cate-

17. Op. cit., pág. 178.

18. Op. cit., pág. 386 . 
goricamente no juízo civil e em quais permanece aberta a discussão na demanda privada.

a Quanto à existência material do fato. O art. 994 do Anteprojeto do Código Civil em exame abrigou a afirmativa de que "não se poderá, porém, questionar mais sobre a existência do fato" quando esta questão se achar decidida no crime.

A regra, portanto, é no sentido de fazer coisa julgada no cível a sentença absolutória que afirmou a inexistência material do fato. A questão não pode ser reaberta na esfera civil. Idêntica ressalva consta do art. 66 do Código de Processo Penal vigente: "Não obstante a sentença absolutória no juízo criminal, a ação civil poderá ser proposta quando não tiver sido, categoricamente, reconhecida a inexistência material do fato."

Vale dizer que, reconhecida categoricamente a inexistência material do fato, a questão não pode ser reaberta no juízo civil.

Este entendimento prevalecerá no futuro, pois o Anteprojeto do Código do Processo Penal, no art. 806, trasladou o mesmo dispositivo do art. 66 da atual lei processual.

b) Quanto às causas de exclusão da antijuridicidade. $\mathrm{O}$ art. 188 do Anteprojeto do Código Civil estatuiu: "Não constituem atos ilícitos: I - Os praticados em legítima defesa ou no exercício regular de um direito reconhecido. II - A deterioração ou destruição da coisa alheia, ou a lesão a pessoa, a fim de remover perigo iminente. Parágrafo único - Neste último caso, o ato será legítimo somente quando as circunstâncias o tornarem absolutamente necessário, não excedendo os limites do indispensável para a remoção do perigo."

Contemplam-se aqui as causas excludentes da antijuridicidade do ato, também chamadas justificativas. Nota-se a falta de uma, inserida no art. 19, $n^{\circ}$ III, primeira parte, do Código Penal vigente, e considerada também no Código Pe- 
nal de 1969, em seu art. 27, inciso III: o estrito cumprimento de dever legal.

Já se sustentou, todavia, à luz do dispositivo do Código Penal de 1940, e do atual Código Civil, cujo artigo 160 é idêntico ao art. 188 acima aludido, que o cumprimento de dever legal está compreendido na expressão "exercício regular de um direito reconhecido" Neste sentido é a opinião de Frederico Marques: "O próprio "cumprimento de dever legal', não explícito no artigo 160 , nele está contido, porquanto atua no exercício regular de um direito reconhecido aquele que pratica um ato 'no estrito cumprimento de dever legal'." 19

E, como autor do Anteprojeto do Código de Processo Penal, o mesmo eminente jurista fez constar expressamente esta justificativa no art. 807, com a seguinte redação: "Faz coisa julgada no cível a sentença penal que reconhecer ter sido $\mathrm{o}$ ato praticado em legítima defesa, estado de necessidade excludente de crime, exercício regular de direito, ou estrito cumprimento do dever legal. Os efeitos civis de qualquer uma dessas excludentes penais ficam subordinados ao que dispuser a legislação de direito privado."

Esta ressalva final do dispositivo tem sua razão de ser No âmbito do direito penal foi amplamente debatida a questão de se saber qual a extensão do reconhecimento de uma das causas de exclusão da antijuridicidade, pela sentença penal absolutória, quanto aos seus efeitos civis.

O fato é que, mesmo no atual Código de Processo Penal, segundo se vê do art. 65, o "estrito cumprimento de dever legal", já estava incluído entre as causas justificativas, suprindo, assim, o claro deixado pelo Código Civil no art. 160.

Caberá reparação do dano, se no juízo criminal se houver afirmado, a favor do réu, a procedência de uma das justificativas legais?

19. Op. cit., pág. 295 . 
Frederico Marques responde pela negativa: "Coincidentes que são as duas áreas das causas excludentes da ilicitude, entendeu o legislador que a decisão do juiz penal sobre qualquer delas, reconhecendo-as como causa de absolvição do acusado, deve ser imutável para o juiz civil. Daí o preceito citado do art. 65, da lei processual." 20

MagalHÃes Noronha acolhe, em princípio, essa argumentação, mäs pondera que "o ato penal lícito nem sempre o é fora desses domínios. No exemplo dado, se A, defendendo-se, não atingir seu agressor mas um terceiro por erro na execução (art. 53) responde civilmente para com o atingido, consoante o determina expressamente o art. 1.540 do Código Civil, mas tem ação regressiva contra aquele, que também lhe assiste, quando, dele se defendendo, danificar coisas de outrem, na forma do art. 1.520, parágrafo único." 21

Em atitude de franca oposição à primeira negativa se encontra Basileu Garcia: "Em outras palavras: o art. 65 do Código de Processo Penal derrogou o Código Civil, nos arts. 1519 e l 540? Que sim, é a opinião de José de Aguiar DIAS, autor do mais completo estudo sobre a responsabilidade civil já escrito em nosso país. E com pesar esse magistrado e escritor exterioriza a sua conclusão, pois lhe parece profundamente censurável a diretriz tomada."

E prossegue o ilustre professor paulista: "Não percebemos, todavia, inconciliabilidade nos referidos preceitos da legislação privada em face do art. 65 do Código de Processo Penal, que não pode ter tido o intuíto de contrastá-los. A linguagem de que a sentença penal absolutória por estado de necessidade, legítima defesa, etc., faz coisa julgada no cível, não tem outro efeito que o de enunciar a impossibilidade de reabrir-se, no setor civil, a discussão sobre a intercorrência dessas justificativas no caso concreto. Mas o legislador pro-

20. Op. cit., pág. 295.

21. E. Magalhäes Noronha, Direito Penal, Saraiva Ed., 6.a Ed., São Paulo, $1970,10^{\circ}$ vol., pág. 307 . 
cessual não dispôs - nem era sua missão fazê-lo - acerca de não caber ou caber, sempre ou às vezes, a indenização, em havendo alguma daquelas justificativas. A tal respeito, o Código de Processo pressupôs o Direito Civil e todas as suas distinções, como, aliás, é normal entender sempre que o antagonismo não seja indubitável." 22

O que parece estar assentado na doutrina, portanto, é que as causas justificativas reconhecidas na sentença penal absolutória se impõem ao reconhecmiento, também, do juiz civil, que não poderá negá-las. Todavia, o decreto absolutório, em tais casos, não veda a via civil para a reparação do dano estranho à própria ação legitimada. Os exemplos dados pelo mencionados autores, relativamente à legítima defesa real, quando é atingido terceiro, que não o agressor, mostra bem a hipótese em que a ação civil reparatória é cabível.

Também assim pensamos. Claro que o oficial de justiça, no cumprimento de dever legal, pode causar danos ao executar uma diligência, ferindo direitos alheios. Responderá por eles. O mesmo se dirá de um agente policial que, no exercício da função, venha a causar danos a uma casa comercial para prender um ladrão

Como vimos, o Anteprojeto do Código de Processo Penal, no art. 807, parte final, dispôs: "Os efeitos civis de qualquer uma dessas excludentes penais ficam subordinados ao que dispuser a legislação de direito privado" Esta ressalva mostra que não são absolutos os efeitos civis da sentença penal absolutória, pelo reconhecimento de qualquer uma das justificativas, resolvenclo-se, a partir da edição do novo estatuto processual penal, o tormentoso problema doutrinário.

Com maior dose de razão, excluem-se os casos de estado de necessidade excludentes de culpabilidade e a legítima defesa putativa. Em relação ao primeiro, o próprio art. 807 do Anteprojeto do Código de Processo Penal implicitamente o

22. Basileu Garcia, Instituições de Direito Penal, Max Limonad Ed., São Paulo, 1952, vol. I, tomo II, págs. 583/584. 
afastou, embora usando de linguagem pouco técnica. Ao enumerar as causas justicativas, referiu-se ao "estado de necessidade excludente de crime" (o grifo é nosso), certamente para distinguí-lo do estado de necessidade excludente de culpabilidade.

Sabido, hoje, que o estado de necessidade pode ser reconhecido como causa excludente da antijuridicidade ou como excludente da culpabilidade, conforme bem o demonstrou Miguel Reale Júnior em sua tese de doutoramento "Dos Estados de Necessidade"

Ora, ao falar em estado de necessidade excludente de crime, o Anteprojeto foi ambíguo, porque também deixa de ser crime o fato a que não se ajunta o requisito da culpabilidade, já que o conceito jurídico do crime inclui este elemento na definição de delito.

Mas, é certo que a exclusão da culpabilidade converte em dirimente a justificativa do estado de necessidade. $\mathrm{O}$ mesmo acontece relativamente à legítima defesa putativa, conforme sucintamente adverte Magalhães Noronha: "Não é necessário dizer que a legítima defesa não abrange a putativa, pois, como já se viu, ela não é justificativa, mas dirimente e para esta outros são os princípios, como se verá." ${ }^{23}$

No mesmo sentido, Basileu Garcia: "A referência não abrange a legítima defesa putativa, que é dirimente e, como tal, sujeita ao influxo de normas diferentes, conforme adiante veremos." 24

c Quanto às causas dirimentes. - $\mathrm{O}$ estado de necessidade excludente da culpabilidade, a legítima defesa putativa e as demais dirimentes previstas no Código Penal, nos arts. $17,18,22$ e 24 , quando reconhecidos na sentença penal absolutória, não impedem a propositura da ação cível. A doutrina é quase unânime nessa afirmativa e com boas razões. Relati-

23. Op. cit., pág. 307 .

24. Op. cit., pág. 582 . 
vamente ao reconhecimento da inimputabilidade do réu assenta Magalhães Noronha, opondo-se à opinião discordante de Basileu Garcia: "Não concordamos, pois, com BasiLEU Garcia, quando sustenta o contrário. Neste caso, não se nega a existência do fato, reconhecida no juízo penal, mas unicamente se verifica e confirma que a absolvição do acusado, por não existirem as condições de imputabilidade, não tem influência na instância civil, porque é lícito exigir a indenização do acusado nessas circunstâncias, por não serem reparáveis somente os prejuízos determinados por atos puníveis. No mesmo sentido Clóvis Bevilaqua."925

Portanto, somente quanto à parte da decisão que afirma a existência do fato e a autoria é que a sentença absolutória penal, pelo reconhecimento de causa dirimente, faz coisa julgada no cível. A reparação do dano, todavia, pode ser demandada, pois o efeito civil da absolvição, nesse caso, não impede o reconhecimento da obrigação de reparar

d Quanto à ausência de provas:

I da existência do fato. - A falta de provas suficientes da existência do fato não se equipara à prova da inexistência do fato. A primeira pode autorizar a absolvição do acusado no juízo criminal, mas persiste a possibilidade de ser reaberta a discussão, integralmente, na instância civil.

Se provada a inexistência do fato, assim julgando o juiz criminal, a questão ficará preclusa, não admitindo nova disputa no juízo civil. Mas, se o caso fôr de absolvição nos termos do art. 386, n. ${ }^{\circ}$ IV, do atual Código de Processo Penal, livre estará a via civil para a solução reparatória .

Observa-se, de passagem, que o Anteprojeto do Código de Processo Penal não repetiu a disiciplina do art. 386 do atual estatuto processual que, na prática, funcionava como verdadeiro norteador do juíz, apontando as causas que autorizavam a absolvição do réu, além de exigir fossem elas explicitadas na sentença.

25. Op. cit., págs. $308 / 309$. 
II da existência do fato típico. - Pode acontecer do juiz criminal decidir que o fato existiu, mas que nẩo se subsume em nenhum tipo penal, deixando, por isso, de ser delituoso. A absolvição, com tal fundamento, não impede também a demanda civil. E o que ensina Frederico Marques: "o ato penalmente lícito pode ser civilmente ilícito. E o que sucede com os fatos não típicos que causam dano a alguém: embora se encontrem excluídos da órbita penal, eles dão causa à indenização civil, porquanto o Código Civil os considera ilícitos (artigo 159)

A sistemática do Anteprojeto do Código Civil adotou a mesma orientação vigente, resultando que seguirá sendo esta a doutrina acertada, tal como hoje é entendida.

Nesta mesma ordem de considerações lembra-se que também não vedam o acesso à via civil, para a reparação do dano, as sentenças que, embora definitivas, deixam de impor pena ao réu, pelo reconhecimento de alguma causa especial de isenção. Tais decisões, comparadas por alguns autores às sentenças absolutórias, na verdade são condenatórias, implicando no julgamento de procedência da ação penal. Somente deixa-se de impor a pena ao réu que, entretanto, terá seu nome lançado no ról dos culpados, firmando-se antecedente para fins de reincidência.

III da existência da autoria ou da co-autoria. - Afirmado pela sentença penal absolutória que o réu não foi o autor do crime, que reconheceu ter existido, tal decisão projetará seus efeitos na instância civil, segundo o expresso dizer do ārt. 994 do Anteprojeto do Código Civil, da mesma forma que, à luz do art. 1525 do vigente Código Civil é entendido. E essa decisão será soberana.

Todavia, a falta de provas suficientes para a afirmação da autoria, ou da co-autoria, embora autorize a absolvição do

26. Op. cit., pág. 294. 
acusado, não impede a reabertura da questão no juízo civil, para os fins de reparação do dano.

Trata-se de uma situação em que o juiz criminal pronuncia o non liquet, à luz dos princípios da justiça penal, que exigem a certeza para a condenação, não bastando indícios. Todavia, na instância civil é possível a perquirição da autoria ou da co-autoria, indefinidas no juízo criminal por falta de provas.

IV - ausência de provas suficientes para a condenação. Este último ítem é quase um resumo de todos os outros já analisados. A ausência de provas suficientes para a condenação implica no juízo de absolvição do réu, dadas as características do julgamento criminal. No entanto, nada impede que a instância civil busque os elementos de convicção necessários para a imposição da reparação do dano, pois são bem outras as exigências para o reconhecimento da culpa na esfera civil.

Convém recordar, com Magalhães Noronha que "Carvalho dos Santos lembra que a decisão do Júri não impedirá a propositura da ação cível, pois, negando o primeiro quesito que engloba a existência do fato e a autoria, nunca se saberá qual das negativas os Jurados afirmaram, não ficando, pois, em boa hora, trancada a via civil." 27

\section{Contravenções e reparação do dano.}

Consoante opinião sustentada por uma corrente doutrinária, os efeitos da condenação previstos no art. 74 do Código Penal não se aplicam às contravenções. Argumentam que, sendo o Direito penal subordinado ao princípio da reserva legal, não se incluiriam as contravenções no referido dispositivo porque, alí, há referência a crime, expressão que é diversa de contravenção.

Se a lei penal aludisse a infração penal, sustenta essa

27. Op. cit., pág. 308 . 
corrente, aí, sim, estariam incluídas as contravenções. Mas, tal não se deu. Referindo-se tão-somente a crime, inaplicáveis seriam os postulados do art. 74 do Código Penal às contravenções .

Contra essa opinião manifestou-se José DuArte: "Dispõe o Código Penal, na Parte Geral, art. 74, aplicável às contravenções, pelo art. $1 .^{\circ}$ do dec.-lei n. ${ }^{\circ} 3.688$, que são efeitos da condenação: I - Tornar certa a obrigação de indenizar o dano resultante de crime" 28

Para este insígne autor, o art. $1 .^{\circ}$ da Lei das Contravenções Penais, ao dispor que "aplicam-se às contravenções as regras gerais do Cód. Penal, sempre que a presente lei não disponha de modo diverso", resolveu inteiramente a questão. Sendo certo que a Lei das Contravenções Penais não se referiu à matéria, implicitamente é de se admitir que às contravenções se aplica a regra geral do art. 74 do Código Penal.

A verdade, porém, é que o interesse relativo a esta questão é escasso. A grande maioria das contravenções corresponde a infrações de mera conduta, em que não há vítima, pois inexiste ofensa material a ser considerada.

Por outro lado é de se recordar que a legislação civil que regula a espécie tornaria despicienda a discussão, pois a resolveu expressamente ao dispor que a reparação é obrigatória quando o dano decorrer de ato ilícito. Ora, a contravenção é ato ilícito, incluindo-se, portanto, na conceituação genérica do Código Civil. Assim sendo, se a conduta contravencional causar, eventualmente, dano, aplicar-se-á, em tudo e por tudo, a mesma disciplina relativa ao delito, no que diz respeito a reparação do dano no juízo civil.

\section{Conclusão.}

De todo o exposto neste trabalho, que demandou espaço

28. Jost Duarte, Comentários à Lei das Contravençóes Penais, Ed. Rev. For., Rio, 1944, pág. 224. 
maior do que pretendíamos inicialmente, dada a complexidade dos temas envolvidos, concluímos que o Anteprojeto do Código Civil Brasileiro não trouxe novidades no seu contexto, quanto à reparação do dano ex-delicto. Sublinhamos que, a par das inovações relativas à adoção com maior destaque das teorias do risco e do dano objetivo, houve um esforçado empenho no sentido de aperfeiçoar os institutos respectivos, empenho esse que pode ser notado na redação mais técnica dos dispositivos legais, visando aprimorar sua conceituação.

No entanto, é preciso que se diga, o Anteprojeto deveria ter atentado com maior acuidade para a solução dos problemas doutrinários, suscitados pelas correntes que se digladiam a respeito dos efeitos civis da sentença absolutória penal, procurando encaminhar soluções concretas, que melhor caberiam nesse diploma legal específico.

A omissão pode ser explicada pela circunstância de vir a jurisprudência solucionando satisfatoriamente as questões surgidas e, também, pela razão de ser mais acesa a disputa entre os penalistas. Mas, a oportunidade seria bem aproveitada se ficassem definidas na lei as soluções julgadas mais corretas.

Observa-se, ainda, que, estranhamente, a inovação mais importante sobre a matéria foi dada pelo Anteprojeto do Código de Processo Penal, ao permitir a execução civil nos próprios autos da ação penal, quando o juiz acumule as jurisdições penal e civil. E, paralelamente, nota-se que o Projeto do Código de Processo Civil, ora em discussão no Congresso, silenciou inteiramente a esse respeito.

Finalmente, poderia o Anteprojeto atualizar alguns conceitos superados, tais como "ferimento" (arts. 1.009 e 1.011), "patrão" e "amo" (art. 991, n." III), substituindo-os por outros que melhor se ajustariam à nossa época. 